\title{
Державно-церковні відносини в західних областях Української РСР: загальні тенденції, локальні особливості (кінець 1970-х - початок 1980-х рр.)
}

УДк 94(477)

DOI https://doi.org/10.24195/2414-

9616.2021-4.7

Пуйда Роман Богданович

кандидат історичних наук, доцент, директор науково-технічної бібліотеки Івано-Франківського національного технічного університету насрти і газу вул. Карпатська, 15, Івано-Франківськ, Україна

\begin{abstract}
Набуття Україною статусу асоційованого та в перспективі повноправного члена Європейського Союзу потребує, з одного боку, створення ефективної нормативноправової бази співробітництва України та Європейського Союзу, а з іншого - інтенсифрікації процесу формування відповідних внутрішніх передумов шляхом проведення системних реформ в усіх сфрерах суспільного життя, утілення ефективної моделі забезпечення національної безпеки, зміцнення демократичних інституцій.

Метою статті визначено дослідження специоріки реалізації євроінтеграційних практик України на основі аналізу нормативно-правового складника моделі співпраці України та Європейського Союзу. Мету розкрито через виконання низки завдань: характеристика основних етапів розвитку євроінтеграційних практик України, визначення досягнень і ризиків на кожному з них, аналіз сучасних проблем реалізації євроінтеграційних практик України. Для досягнення окресленої мети було застосовано систему методів, зокрема нормативного, структурно-функціонального, компаративного, соціологічного, статистичного тощо.

Запропоновано періодизацію формування та реалізації євроінтеграційних практик України на основі аналізу політико-нормативного складника відносин між Україною та ЄС: етап визначення пріоритетів (1991-1998 рр.), етап співпраці та партнерства (1998-2014рр.), етап асоціації та інтеграції (2014р.). Особливістю підготовчого етапу визначено активний процес налагодження взаємовідносин з ЄС, початок формування сталої нормативної бази взаємовідносин Україна - ЄС під час збереження інтересів впливових еліт щодо збереження статусу-кво.

Дослідження другого етапу продемонструвало інтенсифрікацію процесів унормування співпраці Україна - ЄС, адаптації українського законодавства до європейських стандартів, започаткування переговорів щодо створення умов для інтеграції ринку України у спільний ринок ЄС. Водночас серед проблемних аспектів періоду виділено, з одного боку, декларативність ресрорм, відставання у приведенні нормативної бази до європейських стандартів, низьку ефективність інституціональних структур, з іншого - занадто об'ємний для оговореного терміну виконання в три роки перелік зобов'язань, покладених на Україну згідно з Планом дій, неготовність усередині ЄС до більш поглибленої співпраці.

Акцентується на здобутках сучасного етапу асоціації та інтеграції, що підтверджується результатами звіту як уряду, так і громадськості. Водночас сформульовано низку ризиків: корупція, неефективна політика інфрормування населення про євроінтеграцію, відсутність консенсусу в політикумі та соціально-економічні проблеми, російська гібридна агресія, спалах світової пандемії, посилення відцентрових процесів усередині ЄС.

Ключові слова: політика євроінтеграції, євроінтеграційні практики, Європейський Союз.
\end{abstract}

Вступ. На зламі 70-х - 80-х рр. ХХ ст. відбулися помітні зміни у сорері державно-церковних відносин в Українській РСР, адже застійні процеси зачепили не лише соціально-економічну сореру, а й, безумовно, церковно-релігійну, що стало яскраво помітним у західноукраїнських областях - регіоні зі стійкими релігійними традиціями, викорінити які, як показали подальші події, радянській владі так і не вдалося. Зростання релігійної свідомості населення, посилення активності греко-католицьких вірян та духівництва, спроби реєстрації знятих з обліку релігійних громад, самовільні відкриття закритих культових споруд, зменшення впливу атеїстичної пропаганди на місцеве населення базові чинники, які характеризують державно-церковні відносини у західноукраїнських областях досліджуваного періоду.

Історіографрічний огляд. Державно-церковні відносини в Українській РСР уже не перший рік пере- бувають в полі зору українських істориків, релігієзнавців, фрілософрів, політологів, які упродовж останніх 30 років розкрили окремі аспекти проблеми. Узагальнювальні наукові студії учених відображають основну картину політики Центрального Комітету Комуністичної партії Радянського Союзу (ЦК КПРС) у релігійній ссрері, що, зокрема, помітно в дослідженнях О. Бажана, Ю. Данилюка [1], П. Бондарчука [2], В. Войналовича [3], В. Марчука [8], В. Пащенка [9] та інших, проте в них не досить уваги приділено локальним особливостям певних регіонів. Натомість в наукових статтях релігійної тематики, які хронологічно стосуються періоду 1950-х - 1980-х рр., сконцентровано увагу на певних подіях або ж специфріці внутрішньоцерковного життя окремих конфесій. Вищезазначене актуалізує розвідку, яка присвячена церковно-релігійним процесам в західноукраїнських областях і з методологічної точки зору вписується у модерний напрям регіоналізму. 
Основу статті становлять матеріали Центрального державного архіву вищих органів влади України (ЦДАВО України), а також архівні документи місцевих архівів - Державного архіву Львівської області (ДАЛО), Державного архіву Івано-Франківської області (ДАІФО) тощо.

Метою статті $€$ всебічний аналіз церковнорелігійних процесів у західних областях Української РСР на зламі 1970-х - 1980-х рр.

Методологічною основою статті стали загальнонаукові (аналіз і синтез, індукція та дедукція) й спеціально-наукові (науковий опис, кількісний аналіз, критичний аналіз, порівняння аналогій класифрікація, типологічний аналіз, концептуалізація тощо) методи.

Результати. Скрупульозний аналіз документів показує, що для радянсько-партійних органів влади пріоритети державно-церковних відносин у західноукраїнських областях наприкінці 70-х на початку 1980-х рр. залишилися практично без змін із 40-х рр. XX ст. У своїй роботі Рада у справах релігій при Раді Міністрів Української РСР, місцеві уповноважені ради, компартійні чиновники обласного та районного рівнів, силові структури використовували перевірені десятиліттями методи - залякування вірян, репресії над духівництвом, руйнування храмів, поширення атеїстичного світогляду тощо.

Однак суспільно-політичні реалії кінця 70-х початку 80-х рр. XX ст. змушували коригувати політику влади у церковно-релігійній сфері. Один із визначальних чинників - зростання активності «залишків уніатства» у регіоні. Особливе занепокоєння Компартії викликала ситуація у трьох областях - Львівській, Івано-Франківській та Закарпатській. Серйозність проблеми стала очевидною після проведення 14 травня 1976 р. у Львові так званої «кущової наради» уповноважених Ради у справах релігій за участю уповноваженого Ради у Львівській області Б. Іншина, уповноваженого Ради в Тернопільській області В. Старовойта, уповноваженого Ради в Івано-Франківській області C. Гамженка, старшого інспектора уповноваженого Ради у Закарпатській області Е. Юровського та інших [5, с. 86]. Із політико-ідеологічною доповіддю виступив заступник голови Ради у справах релігій Ради Міністрів Української РСР П. Пилипенко, який відзначив, що станом на середину 1970-х рр. в Українській РСР нараховувалося 290 невозз'єднаних греко-католицьких священнослужителів та 445 ченців (у Львівській області 149 священників, в Івано-Франківській - 48, у Тернопільській - 22, у Закарпатській - 71) [5, с. 86].

Врахувавши усі обставини, Рада у справах релігій при Раді Міністрів УРСР вважала за необхідне: продовжити роботу щодо уточнення населених пунктів, в яких ще збереглися впливи грекокатоликів; вдосконалити стиль і методи роботи
3 невозз'єднаним духовенством, чернецтвом і церковним активом; впливати на підвищення рівня громадських комісій для сприяння виконкомам щодо дотримання законодавства про культи; звернути увагу на недопущення на місцях прогалин у роботі з вірянами з боку певних високопосадовців; детальніше вивчати зміст, фрорми і методи ідеологічного впливу буржуазної пропаганди на прихильників уніатства; підвищити відповідальність і вимоги до підготовки працівників, які відповідають за церковно-релігійну сореру тощо [5, с. 98].

Для нейтралізації «уніатських залишків» на зламі 70-х - 80-х рр. XX ст. основні акценти місцевих радянсько-партійних органів влади було перенесено на «особистий діалог» і тотальний контроль за переміщенням духівництва та активних вірян. Зокрема, для протидії поширенню уніатства місцеві органи влади проводили перевірки законності купівлі житла та прописки священнослужителів і вірян. Так, відповідна комісія у Коломиї в 1979 р. виявила, що у місті проживають: 2 вдови «колишніх» греко-католицьких священників пенсійного віку; 6 сиріт «колишніх» греко-католицьких священників, п'ять із яких - пенсіонери, й одна домогосподарка; 12 вдів і 2 сиріт православних священників - пенсіонери; 8 греко-католицьких священників пенсійного віку, які не перейшли на православ'я. Також комісією встановлено, що у Коломиї проживають 17 православних священників. Фактів незаконної прописки комісією виявлено не було [10, с. 43].

Прокурор Івано-Франківської області рекомендував своїм підлеглим: не залишати без уваги жодного порушення «уніатськими вожаками» законодавства про релігійні культи; організувати постійний контроль за священнослужителями ГКЦ; у разі встановлення порушень законодавства уніатами запрошувати їх «на розмову» і відкривати проти священнослужителів кримінальні справи; спільно з правоохоронними органами уважно з'ясовувати кожен оракт продажу, дарунку житлових будівель; рішуче протидіяти спробам уніатів виготовляти і поширювати речі/предмети релігійного спрямування [4, с. 72].

щодо Закарпаття, окрім перелічених засобів боротьби із греко-католицькими вірянами, радянсько-партійні органи влади широко використовували потенціал Російської православної церкви (РПЦ). У цьому контексті відзначимо, що Рада у справах релігій при Раді Міністрів УРСР була незадоволена роботою єпископа МукачівськоУжгородської єпархії РПЦ Сави (О. Бабинець). У 1982 р. він, посилаючись на погане самопочуття, де-сракто самоусунувся від керівництва єпархією. В результаті в області активізували свою діяльність віряни Греко-католицької церкви [11, с. 14].

23 листопада 1982 р. відбулася нарада за участю першого заступника голови Ради у спра- 
вах релігій при Раді Міністрів УРСР П. Пилипенка, уповноваженого Ради у справах релігій у Закарпатській області І. Ващинця, старшого інспектора апарату уповноваженого Ради у справах релігій у Закарпатській області О. Панова, заступника голови виконкому Мукачівської міської ради народних депутатів М. Поповича та єпископа Сави [11, с. 20]. П. Пилипенко зауважив, що у вересні 1981 р. $з$ єпископом Савою обговорювалися два важливих питання. Перше з них стосувалося того, що у Мукачівсько- Ужгородській єпархії «на низькому рівні ведеться боротьба із залишками уніатства у православних приходах», наводилися конкретні приклади церкви у с. Драгово Хустського району, де із хоругв був знятий православний хрест і пришитий греко-католицький, та церкви у с. Воловець, де священник Іваницький проводив хресну ходу на Великдень з елементами греко-католицького культу. Друге питання стосувалося того, що в єпархії не працевлаштовані 16 випускників духовних семінарій [11, с. 21].

Не досягнувши згоди у питанні працевлаштування випускників духовних семінарій у Закарпатській області, П. Пилипенко порушив іншу, не менш важливу, проблему - протидії поширенню уніатства. «У Києві ми з вами багато говорили про боротьбу із залишками уніатства і водночас маємо чимало фрактів, які свідчать про те, що у низці приходів використовуються білі уніатські свічки..., зберігається уніатська атрибутика, - відзначав представник Ради. - Ви не вжили заходів щодо Минайла, Іванця та інших..., наводжу свіжі факти: сьогодні заїхали до церкви у с. Нове Давидково. Там уніатські ікони, хоругви і служебники. Тих служителів потрібно забирати і замінювати іншими священнослужителями під контролем досвідчених православних священників». У відповідь єпископ Сава констатував: «Якщо я всіх православних священників звільню, 3 ким залишусь? 3 самими уніатами?». «Ми подивимось, якусь перестановку будемо робити, - відповів представник Ради у справах релігій. - Ми узгодимо 3 уповноваженим...» [11, с. 24].

П. Пилипенко поставив риторичне питання: «Глобальна проблема для Закарпаття - боротьба 3 уніатством. Хто повинен займатися цим питанням?», і почув однозначну відповідь єпископа Сави: «я!». Останній також зазначив, що не може підібрати «знаючого справу православного священника» замість священнослужителя Минайла i, коли такого знайде, проведе заміну. Завершуючи розмову, єпископ Сава резюмував: «Чому б вам не провести таку розмову з екзархом України. Ми відрізані від православ'я уніатством: сусідством Львівської, Івано-Франківської областей з одного боку та Румунією і Польщею - з іншого» [11, с. 27].

Зрештою, якщо оцінювати есективність вжитих владою заходів щодо нейтралізації активних вірян ГКЦ, виникає чимало запитань. Так, у довідці Львівського обкому Компартії України «Про серйозні недоліки в протидії спробам активізувати католицьку церкву і відновити уніатство в селах Мшана Городоцького, Завадів Стрийського, Мужиловичі Яворівського районів» йшлося про те, що під впливом екстремістів-уніатів деякі віряни с. Мшана Городоцького району з 1978 р. зачіпають питання про реєстрацію так званої Католицької церкви східного обряду, постійно організовують зборище вірян біля закритої культової споруди, порушують громадський порядок у селі. Партійна організація, правління колгоспу «Заповіт Леніна», виконком сільради не вживали рішучих заходів із припинення незаконних дій прихильників уніатства, не домагались освоєння культової споруди для потреб господарства. Атеїстичну роботу нерідко підміняли епізодичними виховними заходами. У селах Завадів і Мужиловичі релігійні об'єднання срактично припинили свою діяльність, але місцеві органи влади своєчасно не подбали про зняття з реєстрації культових споруд і не використовували їх для потреб господарства. Скористалися цим «залишки уніатства», які почали самовільно відкривати церкви і проводити в селах богослужіння за участю екстремістських уніатських священників. Відновлення діяльності православної громади в с. Завадів не призвело до обмеження діяльності в уніатів [7, с. 7-8]

Справді, якщо подивитися на географрію поширення греко-католицького руху у Львівській області, підстави для паніки в партійного керівництва області справді були. Так, серед населених пунктів Львівської області, де проявляли активність греко-католицькі віряни, Львівський обком Компартії України виокремив такі села: у Бродівському районі - Пеняки, Маркопіль, Стиборівка тощо; у Буському районі - Олесько, Утішків, Кудрявці; у Городоцькому районі - Кліцько, Добряни, Березець, Путятичі, Зелений Гай, Нове Село, Градівка, Мости тощо; у Дрогобицькому районі - Верхні Гаї, Смільне, Биків, Снятинка тощо; у Золочівському районі - Поморяни, Зозулі, Вороняки тощо; у Кам'янко-Бузькому районі - Колоденці, Жовтанці, Желдець тощо; у Миколаївському районі - Старий Розділ, Бродки, Новий Розділ, Пісочне, Вербіж тощо; у Мостиському районі - Зав'язанці, Хоросниця, Заріччя, Судова Вишня тощо; у Жовківському (в 1981 р. - Нестерівському) районі - Боянець, Деревня, Зашків, В'язова, Забір'я, Зарудці тощо; у Перемишлянському районі - Ладанці, Тучне, Вовків, Бібрка тощо; у Пустомитівському районі - Давидів, Водяне, Сокільники, Старе Село тощо; у Радехівському районі - Криве, Поздимир, Нестаничі тощо; у Самбірському районі - Подільці, Підгайчики, Вістовичі, Бісковичі, Задністряни тощо; у Сколівському районі - Верхнє Синєвидне, Труханів, Ямельниця тощо; у Сокальському районі - 
Бендюга, Воловин, Добрячин тощо; у Стрийському районі - Завадів, Грибівці, Дідушичі, Воля, Монастирець тощо; у Турківському районі - Мохнате, Матків; в Яворівському районі - Мужиловичі, Добровиця, Калинівка, Рясне тощо [7, с. 12-14].

На тлі боротьби партійно-радянських органів влади з ГКЦ домінувальну позицію в західноукраїнському регіоні займала РПЦ. В інтерв'ю Радіо Київ митрополит Львівський і Тернопільський Миколай (1980 р.), описуючи стан православ'я в західноукраїнських землях, зазначав, що церкви і парафії обслуговуються православним духовенством, яке складається зі священників, котрі здобули освіту в духовних семінаріях та академіях Москви, Ленінграда, Одеси. «Багато молодих священників єпархії здобули ступені кандидатів богослов'я, стверджував митрополит. - До послуг духовенства і вірян - література, що видається Московською патріархією та екзархатом України («Богословські труди», журнал «Православний вісник», книжкові, настінні календарі російською, українською мовами)» [13, с. 43]. Митрополит Миколай констатував, що в єпархії діє кількасот православних церков, які обслуговують 663 священники. Церкви у неділю та свята відвідують віряни, котрі вислуховують богослужіння, проповіді та здійснюють релігійні треби [13, с. 43].

Загалом у доповідній записці Раді у справах релігій при Раді Міністрів УРСР Російська православна церква повідомляла, що на початку 1981 р. в Україні фрункціонували 4163 зареєстровані релігійні громади цієї церкви [10, с. 54]. Щодо фрінансового стану церкви відзначено поступове зростання грошових надходжень. Так, якщо у 1972 р. РПЦ акумулювала 27 млн 967 тис. рублів, то у 1976 р. 30 млн 568 тис. рублів, а в 1980 р. - уже 36 млн 872 тис. рублів. Основним джерелом доходів релігійних громад РПЦ стали: реалізація предметів культу і релігійної літератури (62\%), виконання обрядів (19\%), добровільні пожертви (17\%) [10, с. 54]. Зокрема, якщо у 1978 р. від реалізації предметів культу та релігійної літератури РПЦ отримала 20 млн рублів, то у 1980 р. - уже 23 млн рублів. У 1980 р. вагоме зростання добровільних пожертв спостерігалось у Львівській області, а також на Волині [10, с. 54]. У 1981 р. найзаможніші громади РПЦ функціонували у Донецькій області (3 млн рублів), а також в Одеській та Львівській областях (по 2 млн рублів). Із розрахунку на одну релігійну громаду найменш заможними були релігійні громади в західноукраїнських областях: Закарпатській, Тернопільській, Львівській та Івано-Франківській (2-3 тис. рублів). Загалом у 1980 р. надходження однієї православної громади в середньому у республіці становили 8 тис. рублів [10, с. 55].

Важлива тенденція досліджуваного періоду зростання релігійної активності вірян. Наприклад, в Івано-Франківській області у 1971-1976 рр. на обрядах хрещення, вінчання, поховання зафріксовано близько 420 тис. осіб молодшої і середньої вікових груп. У 1975 р. охрещено 42,6\% від загальної кількості новонароджених, обряд вінчання взяли 12,6\% подружніх пар від загального числа укладених шлюбів, поховання 3 відспівуванням у церкві практикували у 64,8\% випадків від загальної кількості померлих [5, с. 126].

Однак релігійність була неоднаковою серед різних вікових та соціальних груп. Зокрема, невіруюча молодь віком 18-29 років в Івано-Франківській області складала 96,3-97,5\%, віряни серед робітників - 29,5\%, колгоспників - 44,1\%, службовців - 3,2\%. Церкву відвідували 94,2\% вірян, однак щонеділі бували на богослужіннях близько $16 \%$, причащалися 35\%, дотримувалися посту 20,2\% населення. Згідно 3 офріційними документами порівняно з 1971 р. здійснення обряду хрещення знизилося на 12,6\%, вінчання - на 8,8\% [5, с. 137].

Незважаючи на вищезазначене, на початку 1980-х рр. у західноукраїнських областях зберігалася стійка тенденція до проведення релігійних обрядів. У тій же Івано-Франківській області у 1982 р. із загальної кількості новонароджених 1340 осіб було охрещено 633 дитини (47\%). Водночас вінчалися 108 пар (17\%), а поховання за участю священнослужителів відбулись у 88\% випадків. Апарат місцевого уповноваженого Ради у справах релігій відзначав наявність фракту участі в обрядах хрещення і вінчання членів Всесоюзної ленінської комуністичної спілки молоді (ВЛКСМ) $[12$, с. 160$]$.

Результат закономірний, якщо поглянути на роботу радянських пропагандистських органів влади. Власне, у досліджуваний період ефективність роботи атеїстичних бригад, лекторів-агітаторів, місцевих радянсько-партійних органів влади залишалася вкрай низькою. Так, у с. Пороги (Івано-Франківська область) комісія за контролем щодо дотримання законодавства про культи (голова - В. Дроздик), відповідно до звітних документів, «займалася постійною атеїстичною роботою». Про ефрективність такої роботи красномовно свідчать фракти: у 1982 р. із 69 новонароджених дітей 67 були хрещені, а 328 зареєстрованих шлюбів 21 подружня пара вінчалася в церкві. У с. Марків (Івано-Франківська область) із 53 новонароджених 29 - хрещені (54\%), із 17 зареєстрованих шлюбів 8 подружніх пар вінчались у церкві с. Манява. Із 19 померлих у 1982 р. тільки два члени КПРС М. Мундяк і М. Кріца були поховані відповідно до радянської обрядовості, хоча й у цих випадках згодом на їхніх могилах обеліски були замінені на хрести [12, с. 162].

За такої ситуації віряни не тільки проводили релігійні обряди, а й почали вимагати реєстрації релігійних громад. Рада у справах релігій при Раді 
Міністрів Української РСР стурбовано відзначала, що «останнім часом збільшилася кількість заяв і скарг щодо питань реєстрації нових католицьких громад, повернення вірянам раніше закритих костелів та уніатських церков, 981 із яких у Львівській, Івано-Франківській, Тернопільській і Закарпатській областях дотепер не використовуються» [6, с. 228]. Зокрема, у першій половині 1980 р. Рада у справах релігій отримала в 1,3 рази більше листів, ніж за відповідний період 1979 р. Як і раніше, більшість листів надходила із західноукраїнських областей: Львівської - 109 (24\%), Тернопільської - 98 (22\%), Рівненської - 49 (11\%) [6, с. 228].

Зокрема, у лютому 1981 р. віряни РПЦ с. Тарасівка Збаразького району Тернопільської області звернулися до Ради у справах релігій при Раді Міністрів УРСР з вимогою дозволити їм хоча б раз на рік проводити на Великдень богослужіння в місцевій сільській церкві. ще у 1980 р. мешканці села розпочали ремонт у церкві, хоча голова виконкому сільської ради О. Шмигельська запропонувала припинити ремонт. Додамо, що релігійна громада не фрункціонувала із 60-х рp. XX ст., а місцева церква не використовувалась, зважаючи на відсутність священника [10, с. 46].

На початку 1980-х рр. уповноважений ради у справах релігій у Львівській області повідомляв, що віряни РПЦ із таких населених пунктів, як Кулява, Забір'я Нестерівського району, Підлісся Золочівського району, Дусанів Перемишлянського району, Риньяна Старосамбірського району, Моринці Яворівського району, і деяких інших стали направляти в різноманітні інстанції колективні та окремі листи з проханням відновити діяльність їхніх релігійних громад [10, с. 43]. Подібна картина характерна практично для всіх західноукраїнських областей.

Висновки. На зламі 70-X - 80-х рр. XX ст. стан державно-церковних відносин у західноукраїнських областях відзначався зростанням конфрронтації між місцевими органами влади з одного боку та вірянами і духовенством - 3 іншого. Помітна яскрава тенденція до зростання активності греко-католицьких вірян, а також зменшення впливу РПЦ на місцеве населення. За такої ситуації Рада у справах релігій при Раді Міністрів Української РСР зробила основний акцент на індивідуальну «виховну профрілактичну роботу» 3 вірянами та посилення атеїстичної пропаганди, яка повинна була б відштовхнути від церков вірян.

\section{ЛІТЕРАТУРА:}

1. Бажан О., Данилюк В. Випробування вірою: боротьба за реалізацію прав і свобод віруючих в Україні у другій половині 1950-1980-х рр. Київ, 2000. 329 с.
2. Бондарчук П. Релігійна свідомість віруючих УРСР (1940-1980-ті рр.): повсякденні прояви, трансформації. Київ: Інститут історії України НАН України, 2012. $321 \mathrm{c}$

3. Войналович В. Партійно-державна політика щодо релігії та релігійних інституцій в Україні 1940-1960-х рр.: політологічний дискурс. Київ : Світогляд, 2005. $741 \mathrm{c.}$

4. ДАІФО, ф. Р-338, оп. 1, спр. 48, 94 с.

5. ДАІФО, ф. Р-388, оп. 1, спр. 39, 165 c.

6. ДАІФО, ф. Р-388, оп. 1, спр. 44, 256 с.

7. ДАЛО, фр. П-3, оп. 58, спр. 63,78 с.

8. Марчук В. Церква, духовність, нація. Українська греко-католицька церква в суспільному житті України XX ст. Івано-Франківськ : Плай, 2004. 464 с.

9. Пащенко В. Греко-католики в Україні. Від 40-х рр. XX ст. до наших днів. Полтава : ТОВ «Асмі», 2002. $616 \mathrm{c}$.

10. ЦДАВО України, фр. 4648, оп. 6, спр. 162, 145 с.

11. ЦДАВО України, ф. 4648, оп. 7, спр. 217, 142 с.

12. ЦДАВО України, ф. 4648, оп. 8, спр. 207, 215 с.

13. ЦДАВО України. Ф. 4648. оп. 7. спр. 25, 102 с.

\section{REFERENCES:}

1. Bazhan O., Danyliuk V. Vyprobuvannia viroiu: borotba za realizatsiiu prav i svobod viruiuchykh v Ukraini v druhii polovyni 1950-1980-kh rr. [The Test of Faith: The Struggle for the Realization of the Rights and Freedoms of Believers in Ukraine in the Second Half of the 1950s and 1980s], K., 2000, 329 s. (in Ukrainian)

2. Bondarchuk P. Relihiina svidomist viruiuchykh URSR (1940-1980-i roky): povsiakdenni proiavy, transformatsii [Religious consciousness of the believers of the USSR (1940-1980s): everyday manifestations, transformations]. K., 2012, 321 s. (in Ukrainian)

3. DAIFO, f. R-338, op. 1, spr. $48,94 \mathrm{~s}$.

4. DAIFO, f. R-388, op. 1 , spr. 39,65 s.

5. DAIFO, f. R-388, op. 1, spr. 44,56 s.

6. DALO, f. P-3, op. 58, spr. $63,78 \mathrm{~s}$.

7. Marchuk V. Tserkva, dukhovnist, natsiia. Ukrainska hreko-katolytska tserkva $v$ suspilnomu zhytti Ukrainy XX st. [Church, spirituality, nation. Ukrainian Greek Catholic Church in the public life of Ukraine in the twentieth century], Ivano-Frankivsk, 2004, 464 s. (in Ukrainian)

8. Pashchenko V. Hreko-katolyky $v$ Ukraini. Vid 40-kh rr. XX st. do nashykh dniv [Greek Catholics in Ukraine. From the 40s of the twentieth century. to this day], Poltava, 2002, $616 \mathrm{~s}$. (in Ukrainian)

9. TsDAVO Ukrainy, f. 4648, op. 6, spr. 162, 145 s.

10. TsDAVO Ukrainy, f. 4648 , op. 7 , spr. $217,142 \mathrm{~s}$.

11. TsDAVO Ukrainy, f. 4648, op. 8, spr. 207, 215 s.

12. TsDAVO Ukrainy. F. 4648. op. 7. spr. 25, 102 s.

13. Voinalovych V. Partiino-derzhavna polityka shchodo relihii ta relihiinykh instytutsii $v$ Ukraini 1940-1960-kh rokiv: politolohichnyi dyskurs [Party-State Policy on Religion and Religious Institutions in Ukraine in the 1940s and 1960s: Political Science Discourse], K., 2005, 741 s. (in Ukrainian) 


\section{State-church relations in the western regions of the Ukrainian SSR: general trends, local features (late 1970s - early 1980s)}

Puyda Roman Bohdanovych

Candidate of Historical Sciences, Associate Professor,

Director of the Scientific and Technical Library

Ivano-Frankivsk National Technical

University of Oil and Gas

Karpatska str., 15,

Ivano-Frankivsk, Ukraine
The article is devoted to the analysis of state-church relations in the western Ukrainian regions in the final stages of developed socialism (late 70's - early 80's of the twentieth century), in particular reveals: features of the process of revival of the Greek Catholic Church in the region; condition, tendencies among believers of the Russian Orthodox Church (ROC); the specifics of atheistic and propagandistic activities of the Soviet party authorities; activity of believers in the conditions of the Soviet totalitarian system; means of struggle of the Council for Religious Affairs under the Council of Ministers of the Ukrainian SSR against the religiosity of the population and its effectiveness. The purpose of the article is to comprehensively characterize the general trends and local features of state-church relations in the Ukrainian SSR in the context of socio-political and socio-cultural processes because of the analysis of archival documents. It is shown that the main difference between the western Ukrainian region and other regions of the USSR is the high religiosity of the population, most of which belonged to the Greek Catholic Church before the Lviv Pseudo-Council (1946). It is noted that the struggle against believers of all denominations in the period under study did not bring the expected results for local Commissioners for Religions under the Council of Ministers of the Ukrainian SSR, Soviet party authorities, primarily due to "superficiality" and a certain liberalization of all spheres of socio-political life in the republic and reducing the impact of the repressive and punitive system on the population of the region. It is noted that in the western Ukrainian regions the Communist Party of Ukraine recorded a significant percentage of the population, which was marked by religiosity (visiting religious buildings, observance of rituals), which shows the unsuccessful policy of eradicating religious consciousness in the population. It was established that in order to counteract the intensification of religious influence on the population of the western regions of the USSR of the Russian Orthodox Church, as well as to prevent negative anti-social manifestations of "remnants of Uniatism", local Soviet state and party authorities carried out a number of propaganda and mass political in particular, "the reactionary role of the Uniate Church in the history of the Ukrainian people".

Key words: state-church relations, western regions of the Ukrainian SSR, religion, believers, Communist Party of Ukraine, Council for Religions. 